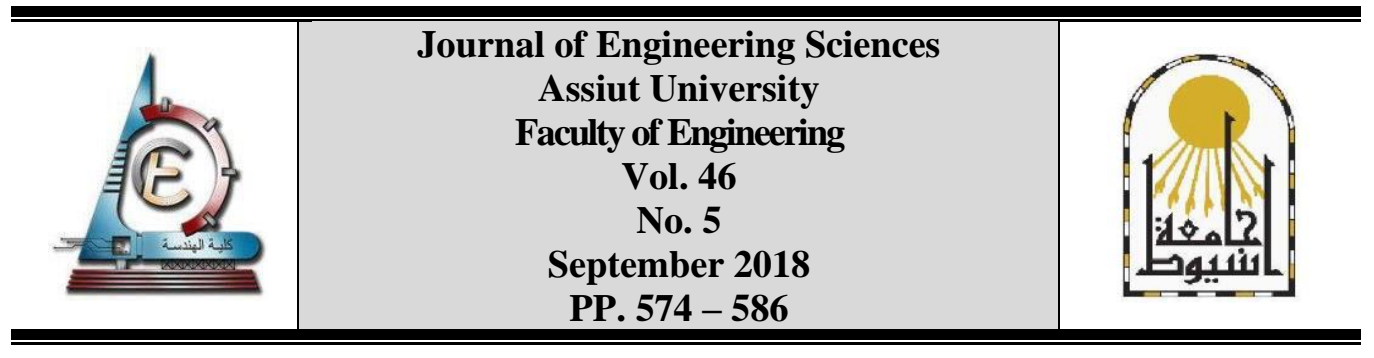

\title{
A STUDY ON THE EFFECT OF PHYSICAL AND MECHANICAL PROPERTIES OF ROCKS ON THEIR GRINDABILITY
}

\author{
Sherein Ahmed M.E. Rizk \\ Faculty of Engineering, Beni-suef University \\ E-Mail address: sherein.rizk@gmail.com/ \\ Received 6 August 2018; Accepted 14 August 2018
}

\begin{abstract}
Grinding processes are very costly because of significant energy requirements to achieve particle reduction. It was estimated that about 5-6\% of the power generated all over the world is consumed in size reduction of raw materials necessary for mineral, cement, and ceramics industries. Mineral processing comminution is always the most energy intensive operation. The energy consumption may vary considerably for different ore types and flowsheets with values ranging from $10 \mathrm{kwh} / \mathrm{t}$ to $30 \mathrm{kwh} / \mathrm{t}$ and corresponding to 30 to $50 \%$ of the total energy cost. Factors affecting the process of comminution include the design and operating parameters of the comminuting machine as well as the physical and mechanical properties of the comminuted rock.

Consequently, the main objective of this work is to study the effect of the most important physical and mechanical properties of rocks on their grindability. It is applied on marble, ilmenite ore and granite samples using a laboratory scale ball mill. The performance of each experiment is measured by the percentage of $-1.25 \mathrm{~mm}$ in the product. $2^{\mathrm{n}}$ factorial method is applied as an experimental design method on each studied rock. Optimum values of the studied operating parameters and their gradation according to their effect on the process are achieved for each studied rock it is concluded that the performance decreases as the compressive strength and hardness of the studied rocks increase and increases as the abrasion value increases. It is also found that optimum values of the studied operating parameters and their gradation depend on the mechanical properties of the studied rocks.
\end{abstract}

Key words: Ball mill, comminution, properties of rocks.

\section{Introduction}

The chief purposes of fine grinding in ore dressing are the liberation of valuable minerals from the accompanied waste minerals of ore to prepare the feed for a specific process requirement such as flotation and cyanidation, and grinding to meet commercial product requirements [1-3]. Grinding can be done dry or wet. Wet grinding is preferable than dry one due to its higher capacity and elimination of the dust problem. On the other hand it consumes more media and liners, and necessity of drying the product.

Size reduction is a result of mechanism which affecting together on the particles. They are impact, abration and chipping [4]. The composite effect of these three mechanisms has been evaluated by considering the size distribution results from $89 \%$ impact, $1 \%$ chipping and $10 \%$ 
abrasion [5]. Tumbling mills such as ball and rod mill are widely used in the mineral and cement industries. Hence, any saving in the cost of operation of these mills can be substantial [6].

Some investigators [7-9] focused their attention to wardrs the decreasing of energy consumption in the process of comminution either by increasing efficiency or suggestion new techniques which depend to a great extent on the properties of the comminuted rocks.

Fuerstenau and Abozeid [7] compared the comminution efficiency of ball milling with single - particle comminution either in terms of the energy to produce a new surface or in terms of some size distribution parameters. Values of about $15 \%$ and $25 \%$ of energy efficiency were obtained from the first and second terms respectively. Hesse et al [8] stated that: selective comminution may be a solution for certain mining operations to increase recovery at lower costs. It exploits selected ore characteristics to enrich valuable mineral in a certain fraction. Love day and NK wanyana [9] used small pebbles $(7-25 \mathrm{~mm})$ in various proportions with balls in a laboratory scale ball mill. They found that the optimum proportion of pebbles, by volume, was $25 \%$ substantial saving in power and ball consumption was achieved with no loss in grinding capacity.

Other investigators [10-18] carried out intensive studies dealing with the important parameters affecting the process of grinding in a ball mill which illustrate the effect of these parameters on the troughput of the mill. Kelly and Spottis wood [10] showed that, there is a definite relationship between troughput of the mill and the speed which the mill rotates. They found that at a speed below $65 \%$ and above $85 \%$ of the critical speed the capacity decreases. Lowrison [11] mentioned that the optimum speed has been found to be between 50 and $75 \%$ of the critical one, but he did not elucidate if it is wet or dry comminution operation. Dealing with the volume of the grinding media, it is concluded that the consumption of balls in the fine grinding of ores is a major item in the costs of milling operations $[12,13]$. Kolacz [13] studied the relation between mill power and its charge. He concluded that: when the mill charged to $40 \%$ of its total volume, the power factor percentage becomes $100 \%$. Currie [14] mentioned that the ball mills normally carry out a ball charge from $40 \%$ to $45 \%$ of the mill volume, but can carry a charge of up to $50 \%$ or slightly higher. Austin [15] gave some lights on the filling ratio between balls. He showed that diagrammatically, too low filling means that balls collide on balls without powder between them, wasting energy by steel on steel contact, as well as too high filling gives cushioning effect. The optimum size of feed which consume minimum power was illustrated to be $-3 \mathrm{~mm}$ [16-18]. Regarding to the size of grinding media, the rate of grinding is increased by increasing ratio of the ball diameter (d) to the particle diameter (b), in fact it is proportion $\sqrt{d / b}$. Material of greater diameter than 0.1 to -0.2 times the ball is not ground [14, 19-25].

Pertaining to the effect of the mechanical properties of the studied rocks on the process of comminution, a few researches have been done in this field. This means that little concerned efforts has been done in this direction, therefore, great deal of attention should be paid towards it. Therefore, the main objective of this work is to study the effect of physical and mechanical properties of the studied rocks on the process of comminution using factorial method as an experimental design one to reduce the number of required experiments to find the optimum values of the studied operating parameters. 


\section{Experimental work}

The tests conducted in this investigation are applied on white marble, ilmenite and granite rocks. The tested rocks are different in their physical and mechanical properties. A sample weighting $20 \mathrm{~kg}$ of each studied rock was taken as a head sample was crushed using the jaw crusher machine with a set adjusted at $10 \mathrm{~mm}$. the crushed product was mixed thoroughly, coned, quartered and divided into two parts. A crushed part weighing $10 \mathrm{~kg}$ was secondary crushed using a roll crusher to $-6 \mathrm{~mm}$. the passed product was screened to obtain $-5+4,-2+1.25 \mathrm{~mm}$ closed fractions by using the manual screening.

The needed weight of each closed fraction for each studied rock was mixed thoroughly and divided by Jones riffle sampler into representative samples, each of about $1 \mathrm{~kg}$ weight. $2^{\mathrm{n}}$ factorial method [26-27] is used to carry out the experimental work of this investigation. Sixteen experiments have been carried out for execution of this method on each studied rock with concerned four parameters. Conditions of these experiments are shown in Table (1).

From the group of factors affecting the ball mill grinding operation, the following parameters are chosen whose influence seems to be the largest [19-21].

1- Particle size of the feed $(\mathrm{P}), \mathrm{mm}$;

2- Time of grinding, (T), minute;

3- Volume of the mill occupied with grinding media charge (V) as a percentage of the total mill volume, \%;

4- Mill speed (S) as a percentage of the critical one, \%.

It should be noted that the choice of the values of the two levels namely the upper and lower ones and the interval of variation are chosen based on the theoretical knowledge, logical reasoning and text books [19-22].

\section{Experimental procedures of grinding}

A cylindrical ball mill of $16 \mathrm{~cm}$ length with an inside diameter of $20 \mathrm{~cm}$ driven by means of two rollers. The mill is filled with the required ball charge of $19.4 \mathrm{~mm}$ size. Volume of voids between balls was measured by water. $90 \%$ of equivalent volume of the certain size of ore is damped and weighted, then fed to the ball mill.

The mill speed was adjusted according to the experimental program given in Table (1). The mill was run for the predetermined time according to the experimental program, and then stopped. The ground ore was dry screened with a screen of $1.25 \mathrm{~mm}$. The product of $1.25 \mathrm{~mm}$ was weighted and taken as the performance of the comminution operation.

Table 1.

Matrix for the planning factorial experimental design.

\begin{tabular}{|c|c|c|c|c|}
\hline Studied factors & $\begin{array}{c}\text { Feed size }(\mathrm{P}), \\
(\mathrm{mm})\end{array}$ & $\begin{array}{c}\text { Time }(\mathrm{T}), \\
(\text { minutes })\end{array}$ & $\begin{array}{c}\text { Vol. occupied } \\
(\mathrm{V}),(\%)\end{array}$ & $\begin{array}{c}\text { Speed } \\
(\mathrm{S}),(\% \text { of c.s. })\end{array}$ \\
\hline Upper level & $-5+4$ & 15 & 60 & 90 \\
\hline Lower level & $-2+1.25$ & 5 & 30 & 60 \\
\hline Exp.No1 & $-2+1.25$ & 5 & 30 & 60 \\
\hline Exp.No 2 & $-5+4$ & 5 & 30 & 60 \\
\hline Exp.No 3 & $-2+1.25$ & 15 & 30 & 60 \\
\hline Exp.No 4 & $-5+4$ & 15 & 30 & 60 \\
\hline Exp.No 5 & $-2+1.25$ & 5 & 60 & 60 \\
\hline
\end{tabular}


Sherein Ahmed M.E. Rizk, A study on the effect of physical and mechanical properties of ........

\begin{tabular}{|c|c|c|c|c|}
\hline Studied factors & $\begin{array}{c}\text { Feed size }(\mathrm{P}), \\
(\mathrm{mm})\end{array}$ & $\begin{array}{c}\text { Time (T), } \\
(\text { minutes })\end{array}$ & $\begin{array}{c}\text { Vol. occupied } \\
(\mathrm{V}),(\%)\end{array}$ & $\begin{array}{c}\text { Speed } \\
(\mathrm{S}),(\% \text { of c.s. })\end{array}$ \\
\hline Exp.No 6 & $-5+4$ & 5 & 60 & 60 \\
\hline Exp.No 7 & $-2+1.25$ & 15 & 60 & 60 \\
\hline Exp.No 8 & $-5+4$ & 15 & 60 & 60 \\
\hline Exp.No 9 & $-2+1.25$ & 5 & 30 & 90 \\
\hline Exp.No 10 & $-5+4$ & 5 & 30 & 90 \\
\hline Exp.No 11 & $-2+1.25$ & 15 & 30 & 90 \\
\hline Exp.No 12 & $-5+4$ & 15 & 30 & 90 \\
\hline Exp.No 13 & $-2+1.25$ & 5 & 60 & 90 \\
\hline Exp.No 14 & $-5+4$ & 5 & 60 & 90 \\
\hline Exp.No 15 & $-2+1.25$ & 15 & 60 & 90 \\
\hline Exp.No 16 & $-5+4$ & 15 & 60 & 90 \\
\hline
\end{tabular}

\section{Determination of some physical and mechanical properties of the studied rocks}

Compressive strength, hardness and abrasion index are appointed for the studied rocks were taken as the important properties affecting the process of comminution.

For compressive stress five samples of each studied rock were tested using the universal testing machine. The tested specimens were cubes of $3 \times 3 \times 3 \mathrm{~cm}$. Specimens were dried for 24 hours in a furnace at $105^{\circ} \mathrm{c}$, and then tested uniaxially. Arithmetic mean of the results of the tested cubes was taken as the compressive strength of each rock.

To execute the hardness test, shmedit hammer is used. Five specimens of each studied rock were tested. Each specimen having dimensions of $10 \times 10 \times 2 \mathrm{~cm}$, was polished and dried. The average results were taken as the hardness value.

Abrasion test machine is used for carrying out the abrasion test. Four specimens of each of $7 \times 7 \times 2 \mathrm{~cm}$ were prepared for each bulk sample of the different studied rocks. The average of the results of the four specimens was taken as the abrasion value. The above mentioned mechanical properties were carried out according to the rock mechanics procedures [28-31].

\section{Statistical approach}

Factorial design is the most efficient way to explore the combinations of variables, because it uses every observation and calls only as many observations as necessary [27]. The essence of the factorial analysis consists in the performance of experiments belonging to one series, changing simultaneously all the tested values called levels and then, so many experiments are carried out that in each subsequent experiment of the combinations of levels of all the factors would occur.

There are several reasons why factorial experiments are often performed with each factors taken at only two levels [28], primarily, the number of experimental conditions in a factorial experiment increases multiplicatively with the numbers of levels of each factor thus, if many factors are to be investigated simultaneously, it may be economically impossible to include more than two levels of each factor. Another important reason is the possibility of the application an easy computational method called (Yates's reduced method) [32, 33].

Such experiments do have some drawbacks, since each factor is measured only at two levels, it's impossible to judge whether the effects produced by variation in a factor are linear, parabolic or exponential. For this reason $2^{\mathrm{n}}$ factorial experiments are often used as a screening method 
which are followed-up by experiments involving fewer factors those found to be "Significant" individually or jointly in the screening experiment taken at more than two levels.

\section{Results and discussions}

If one or two parameter affect the process, it is most easy to investigate their effect, but when the process is affected by many factors, it is important to follow an efficient experimental design method to decrease the number of experiments.

Factorial design is the most efficient way to explore the combination of variables because it uses every observation and calls only for as many observation as necessary. $2^{\text {n }}$ factorial experimentation is often as a screening method, which is followed up by experiments involving power factors (ordinarily), those found to be significant individually or jointly in the screening experiment taken at more than two levels.

\section{Effect of the studied factors on the performance of grinding operation}

Comminution results for the studied rocks at the different studied operating parameters are listed in Table (2). For the purpose of analysing these results, they are arranged in a standard order as shown in table (3). The calculations of this method can be simplified considerably by using short cut called (YATES) [26-27].

This method is illustrated in details tables (3-5)for the different studied rocks. The upper half of each table is obtained by adding successive pairs of the treatment totals, and the lower half is obtained by subtracting them, noting that the first number in each pair is subtracted from the second one, column 2 is then obtained from column 1, and columns 3 and 4 are obtained in the same manner. From entries in columns 2 and 3 and the general column 4 gives the total effect in a standard order. Hence the results of calculations contained in column 4 denote.

- In the line number 1 the sum of the result of all experiments,

- In the line number2,3,5 and 9 the main effects,

- In the remaining lines interactions.

Column 5 contains the sum of squared deviation, indispensable for checking the significance of the respective factors calculated by means of the following equation:

$M_{Z}^{2}=\frac{Z^{2}}{M}$

Where:

M: The number of all experiments,

Z: Factors or interactions.

$M_{Z}^{2}$ : Sum of squared deviation. 
Sherein Ahmed M.E. Rizk, A study on the effect of physical and mechanical properties of ........

Table 2.

Results of experimentations for the different studied materials.

\begin{tabular}{|c|c|c|c|c|c|c|c|}
\hline \multirow{2}{*}{ Exp.NO. } & \multicolumn{3}{|c|}{ Studied factors } & \multicolumn{3}{c|}{ Performance (-1.25mm), \% } \\
\cline { 2 - 8 } & $\begin{array}{c}\mathrm{P} \\
(\mathrm{mm})\end{array}$ & $\begin{array}{c}\mathrm{T} \\
(\mathrm{min})\end{array}$ & $\begin{array}{c}\mathrm{V} \\
(\%)\end{array}$ & $\begin{array}{c}\mathrm{S} \\
(\%)\end{array}$ & Marble & Ilmenite & Granite \\
\hline 1 & $-2+1.25$ & 5 & 30 & 60 & 16.8 & 17.8 & 14.7 \\
\hline 2 & $-5+4$ & 5 & 30 & 60 & 8.3 & 11.9 & 10.1 \\
\hline 3 & $-2+1.25$ & 15 & 30 & 60 & 48.9 & 36 & 38.7 \\
\hline 4 & $-5+4$ & 15 & 30 & 60 & 28.4 & 27.2 & 25.1 \\
\hline 5 & $-2+1.25$ & 5 & 60 & 60 & 13.3 & 15 & 10 \\
\hline 6 & $-5+4$ & 5 & 60 & 60 & 5.9 & 11 & 4.7 \\
\hline 7 & $-2+1.25$ & 15 & 60 & 60 & 38.4 & 31.5 & 26.9 \\
\hline 8 & $-5+4$ & 15 & 60 & 60 & 23.6 & 27.4 & 18.1 \\
\hline 9 & $-2+1.25$ & 5 & 30 & 90 & 26 & 23.7 & 24.1 \\
\hline 10 & $-5+4$ & 5 & 30 & 90 & 13.7 & 19.7 & 17.9 \\
\hline 11 & $-2+1.25$ & 15 & 30 & 90 & 74.4 & 49.8 & 35.6 \\
\hline 12 & $-5+4$ & 15 & 30 & 90 & 49.4 & 45.2 & 42.5 \\
\hline 13 & $-2+1.25$ & 5 & 60 & 90 & 3.7 & 2.7 & 2.1 \\
\hline 14 & $-5+4$ & 5 & 60 & 90 & 2.4 & 2.1 & 1.5 \\
\hline 15 & $-2+1.25$ & 15 & 60 & 90 & 7 & 6.3 & 3.8 \\
\hline 16 & $-5+4$ & 15 & 60 & 90 & 4.5 & 4.4 & 3.1 \\
\hline
\end{tabular}

Table 3.

Calculating the main effects (YATES'S method) for marble.

\begin{tabular}{|c|c|c|c|c|c|c|c|}
\hline $\begin{array}{c}\text { Exp. } \\
\text { No. }\end{array}$ & $\begin{array}{c}\text { Results of } \\
\text { combinations }\end{array}$ & 1 & 2 & 3 & 4 & 5 & $\mathrm{~F}(\mathrm{x})$ \\
\hline 1 & 16.80 & 25.1 & 102.4 & 183.6 & 365.2 & 8335.69 & \\
\hline 2 & $\mathrm{P}=8.30$ & 77.3 & 81.2 & 181.6 & -91.8 & 526.702 & 3.14 \\
\hline 3 & $\mathrm{~T}=48.90$ & 19.2 & 164 & -51.2 & 185 & 2139.06 & 12.8 \\
\hline 4 & $\mathrm{PT}=28.4$ & 62 & 17.6 & -40.6 & -32.8 & 67.24 & \\
\hline 5 & $\mathrm{~V}=13.3$ & 39.7 & -29 & 95 & -167.6 & 1755.61 & 10.5 \\
\hline 6 & $\mathrm{PV}=5.9$ & 124.3 & -22.2 & 90 & 39.8 & 99.003 & \\
\hline 7 & $\mathrm{VT}=38.4$ & 6.1 & -36.8 & -19.4 & -88.6 & 490.623 & \\
\hline 8 & $\mathrm{PVT}=23.6$ & 11.5 & -3.4 & -13.4 & 15.6 & 15.21 & \\
\hline 9 & $\mathrm{~S}=26$ & -8.5 & 52.2 & -21.2 & -2 & 0.25 & 0.0015 \\
\hline 10 & $\mathrm{PS}=13.7$ & -20.5 & 42.2 & -146.4 & 10.6 & 7.023 & \\
\hline 11 & $\mathrm{TS}=74.4$ & -7.4 & 84.6 & 6.8 & -5 & 1.5625 & \\
\hline 12 & $\mathrm{PTS}=49.9$ & -14.8 & 5.4 & 33 & 6 & 2.25 & \\
\hline 13 & $\mathrm{VS}=3.7$ & -12.3 & -12 & -9.4 & -125.2 & 979.69 & \\
\hline 14 & $\mathrm{PVS}=2.4$ & -24.5 & -7.4 & -79.2 & 26.2 & 42.903 & \\
\hline 15 & $\mathrm{VTS}=7$ & -1.3 & -12.2 & 4.6 & -69.8 & 304.503 & \\
\hline 16 & $\mathrm{PVTS}=4.5$ & -2.5 & -1.2 & 11 & 6.4 & 2.56 & \\
\hline
\end{tabular}


Table 4.

Calculating the main effects (YATES'S method) for ilmenite ore.

\begin{tabular}{|c|c|c|c|c|c|c|c|}
\hline $\begin{array}{c}\text { Exp. } \\
\text { No. }\end{array}$ & $\begin{array}{c}\text { Results of } \\
\text { combinations }\end{array}$ & 1 & 2 & 3 & 4 & 5 & $\mathrm{~F}(\mathrm{x})$ \\
\hline 1 & 17.8 & 29.7 & 92.9 & 177.8 & 331.7 & 6876.5 & \\
\hline 2 & $\mathrm{P}=11.9$ & 63.2 & 84.9 & 153.9 & -33.9 & 71.83 & 0.77 \\
\hline 3 & $\mathrm{~T}=36$ & 26 & 138.4 & -22.8 & 123.9 & 959.45 & 10.35 \\
\hline 4 & $\mathrm{PT}=27.2$ & 58.9 & 15.5 & -11.1 & -4.9 & 1.5 & \\
\hline 5 & $\mathrm{~V}=15$ & 43.4 & -14.7 & 66.4 & -130.9 & 1070.9 & 11.55 \\
\hline 6 & $\mathrm{PV}=11$ & 95 & -8.1 & 57.5 & 12.7 & 10.08 & \\
\hline 7 & $\mathrm{TV}=31.5$ & 4.8 & -8.6 & -3 & -46.3 & 133.98 & \\
\hline 8 & $\mathrm{PTV}=27.4$ & 10.7 & -2.5 & -1.9 & 2.1 & 0.28 & \\
\hline 9 & $\mathrm{~S}=23.7$ & -5.9 & 33.5 & -8 & -23.9 & 35.7 & 0.39 \\
\hline 10 & $\mathrm{PS}=19.7$ & -8.8 & 32.9 & -122.9 & 11.7 & 8.56 & \\
\hline 11 & $\mathrm{TS}=49.8$ & -4 & 51.6 & 6.6 & -8.9 & 4.95 & \\
\hline 12 & $\mathrm{PTS}=45.2$ & -4.1 & 5.9 & 6.1 & 1.1 & 0.08 & \\
\hline 13 & $\mathrm{VS}=2.7$ & -4 & -2.9 & -0.6 & -114.9 & 825.13 & \\
\hline 14 & $\mathrm{TVS}=2.1$ & -4.6 & -0.1 & -45.7 & -0.5 & 0.02 & \\
\hline 15 & $\mathrm{VTS}=6.3$ & -0.6 & -0.6 & 2.8 & -45.1 & 127.13 & \\
\hline 16 & $\mathrm{PVTS}=4.4$ & -1.9 & -1.3 & -0.7 & -3.5 & 0.77 & \\
\hline
\end{tabular}

Table 5.

Calculating the main effects (YATES'S method) for granite.

\begin{tabular}{|c|c|c|c|c|c|c|c|}
\hline $\begin{array}{c}\text { Exp. } \\
\text { No. }\end{array}$ & $\begin{array}{c}\text { Results of } \\
\text { combinations }\end{array}$ & 1 & 2 & 3 & 4 & 5 & $\mathrm{~F}(\mathrm{x})$ \\
\hline 1 & 14.7 & 24.8 & 88.6 & 148.3 & 278.9 & 4861.58 & \\
\hline 2 & $\mathrm{P}=10.1$ & 63.8 & 59.7 & 130.6 & -32.9 & 67.65 & 0.31 \\
\hline 3 & $\mathrm{~T}=38.7$ & 14.7 & 120.1 & -32.3 & 108.7 & 738.48 & 3.38 \\
\hline 4 & $\mathrm{PT}=25.1$ & 45 & 10.5 & -0.6 & 0.5 & 0.0156 & \\
\hline 5 & $\mathrm{~V}=10$ & 42 & -18.2 & 69.3 & -138.5 & 1198.89 & 5.5 \\
\hline 6 & $\mathrm{PV}=4.7$ & 78.1 & -14.1 & 39.4 & 2.1 & 0.276 & \\
\hline 7 & $\mathrm{VT}=26.9$ & 3.6 & 0.7 & 12.5 & -41.5 & 107.64 & \\
\hline 8 & $\mathrm{PVT}=18.1$ & 6.9 & -1.3 & 13 & -7.7 & 3.71 & \\
\hline 9 & $\mathrm{~S}=24.1$ & -4.6 & 39 & -28.9 & -17.7 & 19.58 & 0.09 \\
\hline 10 & $\mathrm{PS}=17.9$ & -13.6 & 30.3 & -109.6 & -108.2 & 731.7 & \\
\hline 11 & $\mathrm{TS}=35.6$ & -5.3 & 36.1 & 4.1 & 140.6 & 1235.52 & \\
\hline 12 & $\mathrm{PTS}=42.5$ & -8.8 & 3.3 & -2 & 33.8 & 71.4 & \\
\hline 13 & $\mathrm{VS}=2.1$ & -6.2 & -9 & -8.7 & -80.7 & 407.03 & \\
\hline 14 & $\mathrm{PVS}=1.5$ & 6.9 & -3.5 & -32.8 & -6.1 & 2.33 & \\
\hline 15 & $\mathrm{VTS}=3.8$ & -0.6 & 13.1 & 5.5 & -24.1 & 36.3 & \\
\hline 16 & $\mathrm{PVTS}=3.1$ & -0.7 & -0.1 & -13.2 & -18.7 & 21.86 & \\
\hline
\end{tabular}

The best fit relations calculated from Tables (3-5) are obtained as:

For white marble $\quad: \mathrm{Y}=22.8-5.7 \mathrm{P}+11.6 \mathrm{~T}-10.5 \mathrm{~V}-0.125 \mathrm{~S}$

For ilmenite ore $\quad: \mathrm{Y}=20.73-2.12 \mathrm{P}+7.74 \mathrm{~T}-8.18 \mathrm{~V}-1.49 \mathrm{~S}$ 
Sherein Ahmed M.E. Rizk, A study on the effect of physical and mechanical properties of ........

For granite rock: $: \mathrm{Y}=17.4-2.05 \mathrm{P}+6.8 \mathrm{~T}-8.7 \mathrm{~V}-1.1 \mathrm{~S}$

Where:

P: particle size of the feed, $\mathrm{mm}$;

$\mathrm{T}$ : Time of grinding, min;

$\mathrm{V}$ : volume of the mill occupied with the charge, $\%$ of the total mill volume.

S: Mill speed, \% of the critical speed $\left(\mathrm{N}_{\mathrm{c}}\right)$.

From the regression equations obtained above, the studied parameters affecting the performance of each studied rock can be gradated according to the importance of their effect. If it increases (+) or decreases (-). This behaviour can be interpred as follows:

- The feed size displays a strong negative effect, which shows that, the increase of this factor leads to a decrease in the performance. This behaviour may be due to the unsuitability of the grinding media size to the particles being ground.

- A high positive effect characterizes the time of grinding this means that as the time increases the performance increases. This result is logic, especially with this size of the product.

- The volume occupied with the charge has a strong negative value, which means that the performance decreases with increasing this factor. This behaviour may be attributed to the ball mill becomes crowded which shorten the free falling distance of the media elements.

- The mill speed displays a small negative effect, which is the least value of the effect compared to other values. This trend may be due to changing of the load trajectories from cascading (rolling) to flying (cataracting) which decreases the performance due to the falling of the grinding media elements becomes far from the toe.

\section{Optimization of the studied parameters}

The previously obtained results can be used to find nearly the optimal values of the parameters, by using the "gradient method ". In this method we make use of the fact that the main effects concern the parameters of the process. The regression coefficient "Ai" is calculated basing on the quotient of the main effects of the given factors, rows 2, 3, 5 and 9 and the number of the experiments.

The coefficient of regression calculated by means of these methods, In order to approach a nearly optimal area. As the calculated step of operation proved to be extremely large, it can be reduced ten or hundred fold in order to obtain the actual parameters.

According to the new planned levels of the particles size $(\mathrm{p})$, time of grinding $(\mathrm{t})$ volume occupied with the charge (v) and mill speed (s) three additional experiments were carried out with better results. Tables (6), (7), and (8) show the values of studied parameters at optimal condition for white marble, ilmenite and granite respectively. 
Table 6.

procedures of the new experiments aiming at an optimal case for marble.

\begin{tabular}{|l|c|c|c|c|c|}
\hline & $\mathrm{P},(\mathrm{mm})$ & $\mathrm{T},(\mathrm{min})$ & $\mathrm{V},(\%)$ & $\mathrm{S},(\% \mathrm{Nc})$ & Performance, $(\%)$ \\
\hline fundamental level & 3.07 & 10 & 45 & 75 & \\
-Interval of variation & 1.43 & 5 & 15 & 15 & \\
-Upper level (+) & $-5+4$ & 15 & 60 & 90 & \\
-Lower level (-) & $-2+1.25$ & 5 & 30 & 60 & \\
\hline -Regression coff. & -5.7 & 11.6 & -10.5 & -0.1 & \\
-Operating step & -7.98 & 58 & -157.5 & -1.5 & \\
-Reduced operating step & -0.8 & 5.8 & -15.75 & -0.15 & \\
\hline -Experiment 17 & -2.3 & 15.8 & 30 & 75 & 68 \\
-Experiment 18 & -1.5 & 21.6 & 30 & 75 & 80.1 \\
-Experiment 19 & -0.7 & 27.4 & 30 & 75 & 82.3 \\
\hline
\end{tabular}

Table 7.

procedures of the new experiments aiming at an optimal case for ilmenite.

\begin{tabular}{|l|c|c|c|c|c|}
\hline & $\mathrm{P},(\mathrm{mm})$ & $\mathrm{T},(\mathrm{min})$ & $\mathrm{V},(\%)$ & $\mathrm{S},(\% \mathrm{Nc})$ & Performance, $(\%)$ \\
\hline fundamental level & 3.07 & 10 & 45 & 75 & \\
-Interval of variation & 1.43 & 5 & 15 & 15 & \\
-Upper level (+) & $-5+4$ & 15 & 60 & 90 & \\
-Lower level (-) & $-2+1.25$ & 5 & 30 & 60 & \\
\hline -Regression coff. & -2.1 & 7.7 & -8.2 & -1.5 & \\
-Operating step & -2.9 & 38.5 & -123 & -22.5 & \\
-Reduced operating step & -0.3 & 3.9 & -12.3 & -2.3 & \\
\hline -Experiment 17 & 2.77 & 13.9 & 32.7 & 60 & 40 \\
-Experiment 18 & 2.47 & 17.8 & 32.7 & 60 & 42 \\
-Experiment 19 & 2.17 & 21.7 & 32.7 & 60 & 46 \\
\hline
\end{tabular}

Table 8.

procedures of the new experiments aiming at an optimal case for granite

\begin{tabular}{|l|c|c|c|c|c|}
\hline & $\mathrm{P},(\mathrm{mm})$ & $\mathrm{T},(\mathrm{min})$ & $\mathrm{V},(\%)$ & $\mathrm{S},(\% \mathrm{Nc})$ & Performance, $(\%)$ \\
\hline fundamental level & 3.07 & 10 & 45 & 75 & \\
-Interval of variation & 1.43 & 5 & 15 & 15 & \\
-Upper level (+) & $-5+4$ & 15 & 60 & 90 & \\
-Lower level (-) & $-2+1.25$ & 5 & 30 & 60 & \\
\hline -Regression coff. & -2.05 & 6.8 & -8.7 & -1.1 & \\
-Operating step & -2.93 & 34 & -130.5 & -16.5 & \\
-Reduced operating step & -0.03 & 0.34 & -1.31 & 0.17 & \\
\hline -Experiment 17 & 3.04 & 10.34 & 43.69 & 75 & 18 \\
-Experiment 18 & 3.01 & 10.68 & 42.38 & 75 & 17 \\
-Experiment 19 & 2.98 & 11.02 & 41.07 & 75 & 16.5 \\
\hline
\end{tabular}

\section{Mechanical properties of the studied rocks}

Compressive strength, hardness and abrasion tests were carried out on samples of the studied rocks as the most important technological properties affecting the process of comminution. Results of the study are listed in Table (10). 
Sherein Ahmed M.E. Rizk, A study on the effect of physical and mechanical properties of ........

Table 9.

Mechanical and Physical properties of the studied rocks.

\begin{tabular}{|c|c|c|c|c|}
\hline Rock name & $\begin{array}{c}\text { Comp. strength } \\
\left(\mathrm{kg} / \mathrm{cm}^{2}\right)\end{array}$ & Hardness & $\begin{array}{c}\text { Abrasion value } \\
\left(\mathrm{g} / \mathrm{cm}^{2)}\right.\end{array}$ & $\begin{array}{c}\text { True density } \\
\left(\mathrm{g} / \mathrm{cm}^{3}\right)\end{array}$ \\
\hline Marble & 549.4 & 48 & 0.40 & 2.4 \\
Ilmenite & 630.7 & 50 & 0.38 & 4.5 \\
Granite & 637.1 & 70 & 0.08 & 2.7 \\
\hline
\end{tabular}

Mechanical properties, optimal values of the studied parameters and performance for the different studied rocks are listed in table (10).

Table 10.

mechanical properties, optimal values of the parameters and performance of the studied rocks

\begin{tabular}{|c|c|c|c|c|c|c|c|c|}
\hline \multirow{2}{*}{$\begin{array}{c}\text { Rock } \\
\text { name }\end{array}$} & \multicolumn{3}{|c|}{ Mechanical properties } & \multicolumn{3}{c|}{ Optimal values of the parameters } & Performance \\
\cline { 2 - 7 } & $\begin{array}{c}\text { Comp. } \\
\text { str. } \\
\left(\mathrm{kg} / \mathrm{cm}^{2}\right)\end{array}$ & Hardness & $\begin{array}{c}\text { Abrasion } \\
\text { value } \\
\left(\mathrm{g} / \mathrm{cm}^{2}\right)\end{array}$ & $\begin{array}{c}\mathrm{P} \\
(\mathrm{mm})\end{array}$ & $\begin{array}{c}\mathrm{T} \\
(\mathrm{min} .)\end{array}$ & $\begin{array}{c}\mathrm{V} \\
(\%)\end{array}$ & $\begin{array}{c}\mathrm{S} \\
(\% \mathrm{Nc})\end{array}$ & \\
\hline Marble & 549.4 & 48 & 0.40 & 0.61 & 27.4 & 30 & 75 & 82.3 \\
Ilmenite & 630.7 & 50 & 0.38 & 2.2 & 21.7 & 32.7 & 68 & 46 \\
Granite & 637.1 & 70 & 0.08 & 3.04 & 10.34 & 44 & 75 & 18 \\
\hline
\end{tabular}

From table (10) it is clear that the optimum performance increases with decreasing of compressive strength as well as hardness as mechanical properties of the studied rocks. On the other hand the optimum performance increases as the feed particle size and the volume of mill occupied decrease as optimal operating parameters.

On the other hand, the optimum performance increases as the property abrasion value increases as a mechanical properties and increases also as the time of grinding and mill speed increase as optimum operating parameters.

\section{Conclusions}

From this investigation it can be concluded that:

-There is a direct proportionality between the optimum performance and the abrasion value (as a mechanical property) as well as optimum time of grinding and optimum grinding speed (as operating parameters).

On the other hand there is a reverse proportionality between the optimum performance and compressive strength and hardness (as mechanical properties) as well as feed particle size and volume of mill occupied (as operating parameters).

-Application of the statistical planning of experimental methods is reasonable in mineral processing; as it decreases the number of experiments, consequently a small amount of ore; less effort and a short time are achieved.

Factorial design method facilitates the possibility of selecting the most affecting parameters because it gradates them according to their effects, consequently, the studied operating parameters can be gradated as follows:

1-Volume of the mill occupied with the charge.

2- Time of grinding. 
3- Particle size of feed.

4-Mill speed as a percentage of the critical speed.

The produced regression models are represented by the following equations:

- $\quad \mathrm{Y}=22.80-5.7 \mathrm{P}+11.6 \mathrm{~T}-10.50 \mathrm{~V}-0.125 \mathrm{~S}$ for marble.

- $Y=20.73-2.12 \mathrm{P}+7.74 \mathrm{~T}-8.18 \mathrm{~V}-1.49 \mathrm{~S}$ for ilmenite.

- $Y=17.4-2.05 p+6.8 T-8.7 \mathrm{~V}-1.1 \mathrm{~S} \quad$ for granite.

It is recommended to apply this study on a pilot plant as a scaling up step.

\section{Acknowledgement}

The author would like to express his deep appreciation to the staff members and laboratories technicians of Mineral Processing branch at Mining and Metall.Engng.Dept. Faculty of Engineering, Assiut University, for their encouragement, help and co-operation.

\section{REFERENCES}

[1] Palm, N.A., Shackleton, N.J., Malysiak, V. and Oconor, C.T., "The effect of using different comminution procedures on the flotation of sphalerite", Minerals Engng., 23 (2010) 10531057.

[2] Eksi, D., Benzer, A.H, Sargin, A., and Genc.O., "A new method for determination of fine particle breakage", Minerals Engng., 24 (2011) 216-220.

[3] Ozcan, O., and Benzer, H., "Comparison of different breakage mekanisms in terms of particle size distribution and mineral liberation", Minerals Engng., 49 (2013) 103-108.

[4] Mends, S., Stenger, F., Peukert, W and, Schweroles, J., "Production of sub-micron particles by wet comminution in stirred media mill" J. of Materials Science, 39 (2004) 5222352226.

[5] Cho, H., Kwon, J., Kim, K., and Mun, M., "Optimum choice of the make-up sizes for maximum troughput in tumbling ball mills", Powder Technology, 240 (2013) 625-634.

[6] Chimwani, N., Mulenga, F.K., and Hildebrandt, D., "Ball size distribution for the maximum production of a narrowly-sized mill product powder technology, 284 (2015) 1218.

[7] Fuerstenau, D.W.and Abouzeid, A.-Z.M., "The energy efficiency of ball milling in comminution", Int.J. Mineral Process, 67 (2002) 161-185.

[8] Hesse, M., Popov, O. and Lieberwirth, H., "Increasing efficiency by selective comminution", Minerals Engng., 103-104 (2017) 112-126.

[9] NKwanyana, S. and Loveday, B., "Addition of pebbles to a ball mill to improve grinding efficiency", Minerals Engng., 103-104 (2017) 72-77.

[10] Kelly.G.C., and Spottiswood, D.J., "Introduction to mineral processing", John Willey and Sons, New york, (1982).

[11] Lowrison, G.C., "Crushing and grinding", London, (1974).

[12] Herbst, J.A. and Fuerstenau, J.A., "Influence of mill speed and ball loading on the parameters of the batch grinding equations", Trans.of AIME, Vol.252, (1972) pp.169-176.

[13] Kolacz, "Control of the mill charge behavior in dry tumbling mills" J. of Material Science, 39 (2004), pp 52223-52226.

[14] Currie, J.M., "Unit operations in mineral processing", Reprinted CMS, January (1978).

[15] Austin, L.G., "Concepts in the process design of mills", Mining Engng., June (1984).

[16] Verms, R.V. and Rajamini, "Environment-dependent breakage rates in ball milling" Powder Techn., Vol.84 (1995), pp.127-137.

[17] Ballantyne, G.R., and Powell, M.S., "Bench marking comminution energy consumption for the processing of copper and gold ores", Minerals Engng. 65 (2014) 109-114. 
Sherein Ahmed M.E. Rizk, A study on the effect of physical and mechanical properties of ........

[18] Shi, F.and Xie, W., "A specific energy based size reduction model for batch grinding ball mill", Minerals Engng., 70 (2015) 130-140.

[19] Vijayendra, H.G., "A handbook on mineral dressing", Vikas Publishing House PVT LTD, Second Edition, (2001).

[20] Jain, S.K., "Mineral processing", Second Edition, CBS publishers and Distributors.LTD., New Delhi, India, (2011).

[21] Fuerstenau, M.C.and Han, K.N. [editors], "Principles of mineral processing", Society of Mining, Metallurgy and Exploration, Inc (SME) USA, (2003).

[22] Malhotra, D., Taylor, P.R., Spiller, E.and Levier, M. [Editors], "Recent advances in mineral processing plant design", Published by SME, USA, (2009).

[23] Dalla, A.and Rajamani, R.k., "A direct approach of modeling batch grinding in ball mills using population balance principles and impact energy distribution", Int.J.Min.Process, Vol.64, pp.181-200, (2002).

[24] Dong, H.and Moys, M.H., "Load behavior and mill power", Int.J.Miner.Process, Vol.69, pp.11-28 (2003).

[25] Dong, H.and Moys.M.H., "Measurement of impact behavior between balls and walls in grinding mills", Minerals Engng, 16 (2003) 543-550.

[26] Adler, Y.P., Markov, E.V.and Granovsky, "The design of experiments to find optimal conditions" Mir publisher, Moscow, (1975).

[27] Miller, R.E., "CE tutorial, part 10, Experimental design", Chem.Engng. June (1986).

[28] Vutukuri, V.S.lama, R.D., and Saluja, S.S., "Hand book on mechanical properties of rocks", Test Techniques and Results", Vol.I, First Edition, TRANS.TECH.PUPLICATIONS.(1974).

[29] Chunantang and Hudson, J.A., Rock failure mechanisms", Taylor and Francis Group, London, UK, (2010).

[30] Reheysky, Y., and Novik, G., "The physics of rocks", Mir Publishers, Moscow, (1971).

[31] Conca, J.L., and Cubba, R., "Abrasion resistance, hardness testing of rocks", Int.J.Rock Mech. Min.Sci.and Geomech. Abs. Vol.23, No.2, pp.141-149, April (1986).

[32] Davis, O.L., (Editors), "The design and analysis of industrial experiments "Edinburgh, Sec.Ed., (1971).

[33] Davis, O.L.and Goldsmith, P.L., (Editors), "Statistical methods in research and production", Edinburgh, Fourth Ed.(1972). 


\section{دراسة عن تأثثير الخواص الطبيعية والميكانيكية للصخور على قابلية طحنها}

\section{الملخص العربى:}

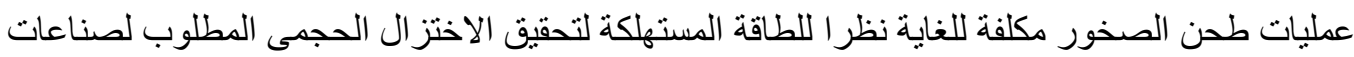

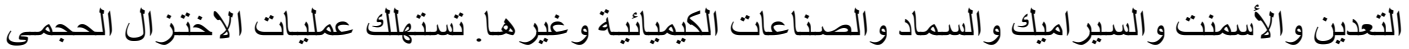

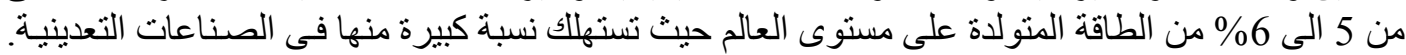

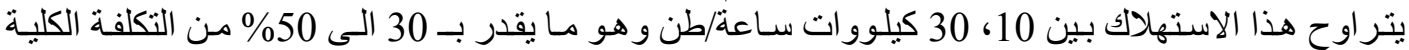
لاعداد الخام للصناعة.

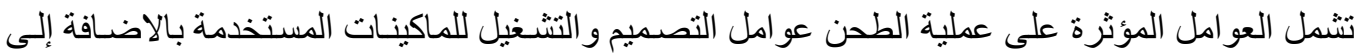

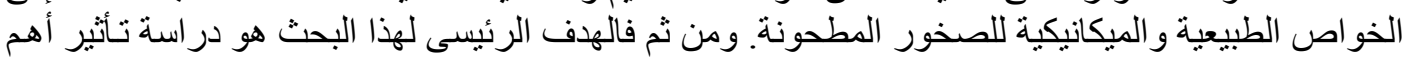
الخو اص الطبيعية و الميكانيكية للصنور الطيكية للصغور على طحنها.

طبقت الدر اسة على صخور الرخام والألمينيت و الجر انيت المختلفة الخو اص باستخدام طريقة العو امل

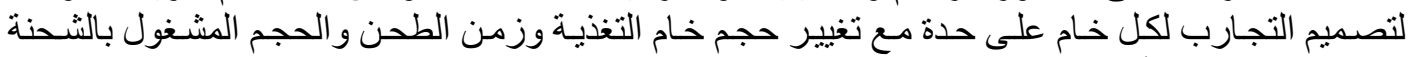
وسر عة الطاحونة كأهم عو امل التشخيل المؤثرة على انتاجية طاحونـة الكر ات على مقياس معملى. وتـم تقيبم

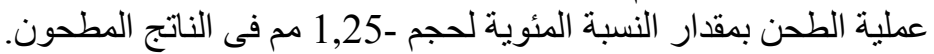

وقد خلصت الدر اسة الى وجود علاقة عكسية بين ناتج الطحن وكل من قوة تحمل الصخر لاجهاد الضغط و الصلادة وطردية مع خاصية البرى.

كما تم استتاج معادلات تجريبية تربط بين العو امل المدروسة و إنتاجية الطاحونة على مقئ مقيساس معملى لكل

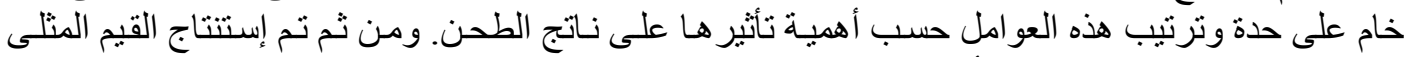

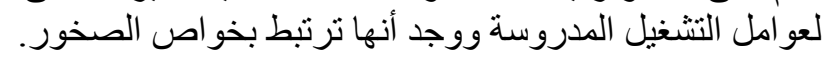

